\title{
Contributions of young chemists to analytical chemistry
}

\author{
Karel Nesměrák ${ }^{1}\left[\right.$. Tomáš Navrátil ${ }^{2}$
}

Received: 17 July 2020 / Accepted: 18 July 2020 / Published online: 23 July 2020

(c) Springer-Verlag GmbH Austria, part of Springer Nature 2020

Dear readers,

In this special issue of Monatshefte für Chemie-Chemical Monthly you will find a nice selection of papers focusing on various aspects of analytical chemistry, written by young chemists at the very beginning of their scientific career. As we are all aware, the reproduction and development of such crucial science as it is analytical chemistry chiefly depends on the young scientists, who-in co-operation and dialogue with their more experienced colleagues-could bring new, unsuspected views and ideas. With generous consent of the Editor-in-Chief of the journal, Prof. Dr. Peter Gärtner, it is our pleasure to present here 16 papers written by Ph.D. students of analytical chemistry from various European countries. In this way, we would like to support their research activities in the field of analytical chemistry and to improve their skills of scientific writing.

The topics of papers presented in this issue cover a number of aspects of modern analytical chemistry from theoretical problems, through development of new analytical methods or improvement of analytical techniques, to their application on medicinal, environmental, or historical problems. Thus, the issue represents a nice opportunity to foresee perspectives on the development of analytical chemistry.
Let us hope that all readers will find presented papers interesting and they will be assured that a new generation of analytical chemists could secure bright and exciting future of our science. Only that analytical chemistry will remain rewarding, exciting, steadily developing science with vivid perspectives, and especially usable for the good of humanity.

As Editors of this special issue, we take the opportunity to express our deep gratitude to the Editor-in-Chief, Prof. Dr. Peter Gärtner, and the Managing Editor, Dr. Christian Hametner, for their kind support in the preparation of this issue. We would like to thank all referees for valuable comments that improved the quality of the papers, and to the staff of the Publisher, Springer-Verlag GmbH Austria, for all their help with the special issue release.

Enjoy reading this issue,

Karel Nesměrák and Tomáš Navrátil.

Publisher's Note Springer Nature remains neutral with regard to jurisdictional claims in published maps and institutional affiliations.

Karel Nesměrák

nesmerak@natur.cuni.cz

1 Department of Analytical Chemistry, Faculty of Science, Charles University, Prague, Czech Republic

2 J. Heyrovský Institute of Physical Chemistry of the Czech Academy of Sciences, Prague, Czech Republic 